\title{
Will representation targets based on area protect critical resources for the conservation of the Tucuman Parrot?
}

\author{
Anna M. Pidgeon, ${ }^{1 *}$ Luis Rivera, ${ }^{2}$ Sebastian Martinuzzi, ${ }^{1}$ Natalia Politi, ${ }^{2}$ and Brooke Bateman ${ }^{1}$ \\ 1 Department of Forest and Wildlife Ecology, University of Wisconsin-Madison, Madison, Wisconsin, USA \\ 2 Facultad de Ciencias Agrarias, Universidad Nacional de Jujuy, CONICET, Jujuy, Argentina \\ * Corresponding author: apidgeon@wisc.edu \\ Submitted December 19, 2014; Accepted June 26, 2015; Published September 9, 2015
}

\begin{abstract}
The Tucuman Parrot (Amazona tucumana), which is restricted to Southern Yungas forest of Argentina and Bolivia, has not recovered from severe population declines in the 1980s. We assessed habitat conservation targets for this species and asked, "What constitutes the right target?" For species with small ranges, maximizing the proportion of the range under protection is an established strategy to safeguard against threats. However, designating an amount for protection based on range alone (i.e. a 'representation target') may set a misguided conservation target if critical resources are not considered. We used an ensemble model ('biomod2') to map suitable breeding and nonbreeding habitat of the Tucuman Parrot based on environmental variables and key resources (breeding) or the species' occurrence (nonbreeding). Pino blanco (Podocarpus parlatorei) seeds are critical food for Tucuman Parrot nestlings, so we modeled the distribution of this tree as a proxy for potential breeding habitat. We then examined the adequacy of current habitat protection relative to representation targets and in light of known threats, including forest degradation and loss, and poaching. Overall, $17 \%$ of the $110,122 \mathrm{~km}^{2}$ Southern Yungas is protected, which is close to the proportion recommended (the target; 22\%), based on the ecoregion's size, for inclusion in a conservation network. Similarly, $26 \%$ of the $46,263 \mathrm{~km}^{2}$ of nonbreeding habitat is protected, also relatively successful at $71 \%$ of the target (36\%). However, of the scant $\sim 21,000 \mathrm{~km}^{2}$ of breeding habitat, only $15 \%$ is protected, much less than the representation target $(49 \%)$ recommended for maximizing the probability of population persistence. Poaching of nestlings further undermines the value of some nesting habitat in Bolivia. For Tucuman Parrots, increased enforcement of protection in Bolivia and protection of additional nesting habitat in Argentina are the most efficient ways to enhance persistence. Our results illustrate how habitat conservation targets based on area alone may be inadequate if important biological information is overlooked.
\end{abstract}

Keywords: Argentina, Bolivia, ensemble species distribution modeling, Podocarpus parlatorei, protected areas, Yungas

La representación de objetivos basados en área, ¿protegen los recursos críticos para la conservación del Loro Alisero?

\section{RESUMEN}

El Amazona tucumana es una especie restringida a las Yungas australes de Argentina y Bolivia que no se ha recuperado de la severa declinación de sus poblaciones durante la década de los 80 s. Evaluamos los objetivos de conservación del hábitat del Amazona tucumana y nos preguntamos, ¿cual constituye el objetivo adecuado? Maximizar la proporción del área bajo protección de especies con rangos pequeños es una estrategia común para resguardarlas de eventos estocásticos y de otras amenazas. Sin embargo, basar la designación de la cantidad de área a proteger sólo en su rango (es decir, en un objetivo de representación) puede ser un objetivo de conservación erróneo si no se consideran los recursos críticos para la especie. En este trabajo utilizamos un modelo conjunto ('biomod2') para mapear el hábitat reproductivo y no reproductivo adecuado para el Amazona tucumana basado en variables ambientales y recursos clave (durante la época reproductiva) o en la ocurrencia de la especie (en la época no reproductiva). Las semillas de Podocarpus parlatorei constituyen un alimento crítico para los pichones de Amazona tucumana, por lo que modelamos la distribución de esta especie de árbol como una representación del hábitat reproductivo potencial. Luego examinamos si es adecuada la protección actual de su hábitat en relación a objetivos de representación y a la luz de las amenazas conocidas, incluyendo la degradación y pérdida de bosque y la extracción de pichones. En total, el 17\% de los $110,122 \mathrm{~km}^{2}$ de Yungas australes están protegidos, lo cual está cerca de la proporción recomendada (22\%) para ser incluido en un sistema de áreas de conservación, basado en el tamaño de la ecorregión. De igual manera, el $26 \%$ de los $46,263 \mathrm{~km}^{2}$ de hábitat no reproductivo está protegido, siendo relativamente exitoso al alcanzar el $71 \%$ del objetivo de conservación (36\%). Sin embargo, de los escasos $\sim 21,000 \mathrm{~km}^{2}$ de hábitat reproductivo, solamente el $15 \%$ está 
protegido, mucho menos que el objetivo de representación (49\%) recomendable para una probabilidad máxima de persistencia de la población. La extracción de pichones además, disminuye el valor de algunos hábitats de nidificación de la especie en Bolivia. Para el Amazona tucumana, un mayor cumplimiento de su protección en Bolivia y la protección de hábitat de nidificación adicional en Argentina sería la forma más eficiente de mejorar sus posibilidades de persistencia. Nuestros resultados muestran como los objetivos de conservación de hábitat basados solamente en área pueden ser inadecuados si la información biológica importante es soslayada.

Palabras clave: Argentina, Bolivia, modelado conjunto de distribución de especies, Podocarpus parlatorei, áreas protegidas, Yungas

\section{INTRODUCTION}

The Southern Yungas ecoregion is located on the eastern slopes of the Andes, extending from southeastern Bolivia to northwestern Argentina (Fjeldså and Krabbe 1990). The endemic Tucuman Parrot (or Tucumán Parrot; Amazona tucumana) occurs only in Southern Yungas forest, and suffered a severe population decline in the 1980s from which it has not recovered due to capture for the pet trade (Rivera et al. 2010), forest degradation, logging of pino blanco (Podocarpus parlatorei; Politi et al. 2009), a key food resource for nestlings (Rivera 2011), and range contraction in at least the southern-most extent (Rivera et al. 2007, 2010, 2013). The species is categorized as 'Vulnerable' by the International Union for the Conservation of Nature (IUCN 2014). In both Bolivia and Argentina, conservation of the Tucuman Parrot centers on protected areas, which have been established at different administrative levels (e.g., federal, provincial, and municipal) and vary in the degree to which they restrict human activities. Stricter protection is accompanied by a lower threshold for activities that degrade habitat (Ferraro et al. 2013).

Effective protected areas include habitat that is required by species of conservation concern and that is free from conditions and activities that threaten those species' persistence (Margules and Pressey 2000). In analyzing the effectiveness of a regional protected area network, the representation of specific habitat or ecosystem types within the network is a frequently used criterion (e.g., Long et al. 1996, Rodrigues et al. 2004, Svancara et al. 2005, Tear et al. 2005, Maria Mendoza and Arita 2014). The concept of representation includes consideration of the degree to which protected areas reflect the natural variety of habitats of a region (Margules et al. 2002). One conservation target that is both intuitive and easy to monitor is protection of a fixed percentage of each habitat type.

Targets for the amount of habitat that needs to be protected to safeguard an individual species must be tailored according to the species' range size (Rodrigues et al. 2004, Tear et al. 2005). While $10 \%$ is considered a sufficient conservation representation target for widely distributed species or habitats (Brooks et al. 2004), an adequate target for a species with very limited distribution is considerably higher (Kukkala and Moilanen 2012). Species with small ranges are a priori of conservation concern (Rosenfield 2002) because they are vulnerable to stochastic threats such as extreme weather events, epidemic diseases, novel predator invasions, and, if they are dietary specialists, fluctuations in food availability. Thus, a representation target of up to $100 \%$ may be considered precautionary for species with ranges smaller than $1,000 \mathrm{~km}^{2}$ (Rodrigues et al. 2004).

However, conservation targets that are based only on the range of a given species do not necessarily capture the finer-scale distribution of critical habitat elements within the range (Margules et al. 2002). Species may depend on a small portion of their range, or on a narrow set of features, for certain important activities, such as mating, raising young, migrating, and foraging. If this is the case, the overall percentage of the range that is protected may have limited relevance if critical sites or features are not protected.

Two critical features of suitable Tucuman Parrot breeding habitat are tree cavities for nesting and an adequate population of mature pino blanco, an endemic cloud forest coniferous tree species (Rivera et al. 2012). Nestling and juvenile Tucuman Parrots feed so heavily on pino blanco seeds that the trees may be essential for the survival of juvenile parrots (Rivera 2011; Figure 1). Tucuman Parrot nests are only found within $1 \mathrm{~km}$ of mature pino blanco trees, which occur within cloud forest (Politi et al. 2009). Years of high mast production coincide with high Tucuman Parrot nest density (Rivera 2011). Given the decline of the Tucuman Parrot population and the specificity of its breeding habitat requirements, we need to know whether protected areas include these critical areas for breeding. An analysis of potential gaps in protection across the whole of the ecoregion, and specifically for breeding habitat, is a necessary step for guiding conservation priorities (Jennings 2000, Kukkala and Moilanen 2012).

While the protection of key features for all life stages is essential to successful conservation outcomes, so too is specifying legal activities within protected areas and enforcing these laws. If a protected area is managed for multiple goals, such as sustainable natural resource use as well as biodiversity conservation, then the definition of 


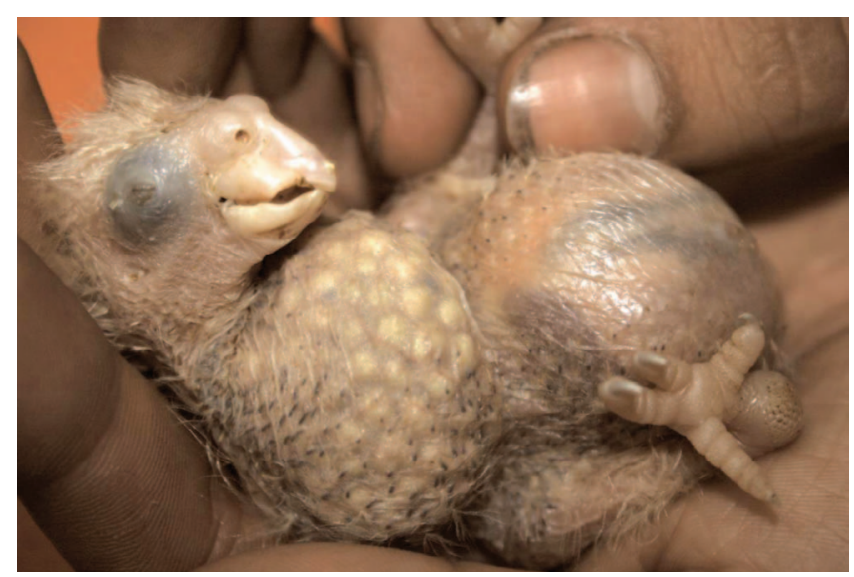

FIGURE 1. Tucuman Parrot (Amazona tucumana), $\sim 1$ week old. Seeds of the conifer pino blanco (Podocarpus parlatorei) in the nestling's crop can be seen through the skin. This is the primary food provided to nestlings by their parents during the first 6-7 weeks of life. Photo credit: L. Rivera

'sustainable' must be carefully chosen to assure that conservation goals can be met (Lunney et al. 1997). For charismatic species such as parrots, the threat of poaching for the pet trade is additive to the pressures of habitat loss and degradation.

Legal export of Tucuman Parrots from Argentina and Bolivia was high in the 1980s (Rivera et al. 2010), but importation into the U.S. was banned in 1992 (U.S. Fish and Wildlife Service 1992), and importation into the European Union was banned in 2005 (http://www. legislation.gov.uk/uksi/2005/1674/regulation/3/made). In Bolivia, however, it is not uncommon to see Tucuman Parrots kept as pets (L. Rivera personal observation, J. Tella personal communication). Extraction continues for local trade, with entire broods removed from nests in Bolivia in protected and unprotected areas (Rivera et al. 2010).

Poaching rates are affected by the presence of protection programs, by geographic region, and by domestic trade within countries (Wright et al. 2001, Beissinger 2013). Across the Neotropics, poaching is thought to be lower in protected than unprotected sites (Wright et al. 2001). While details of enforcement efforts within protected areas of Bolivia and Argentina are unclear, in many developing countries management and enforcement have not kept pace with need (Bruner et al. 2004). For the Tucuman Parrot specifically, the estimated shortfall in expenditure to reduce the risk of extinction sufficiently to down-list it from 'Vulnerable' to 'Near Threatened' in the next 10 years is $\sim$ US\$402,000 annually (McCarthy et al. 2012). Thus, the degree to which Argentina's and Bolivia's protected areas represent critical pino blanco forest habitat and provide adequate protection for breeding Tucuman Parrots is not clear.
Our goal was to compare conservation targets for different components of habitat of the Tucuman Parrot and the degree of success in achieving them. We also evaluated the level to which pino blanco and mature cavity-containing trees are secured by the protected areas network. As part of that determination we sought to: (1) map potential breeding and nonbreeding habitat for the Tucuman Parrot; (2) assess the representation and adequacy of currently protected areas for the Southern Yungas ecoregion as a whole, and of both breeding and nonbreeding habitat separately; and (3) make recommendations for additional conservation actions.

\section{METHODS}

\section{Study Area and Species}

The Southern Yungas ecoregion is located on the eastern slopes of the Andes between $\sim 14^{\circ} \mathrm{S}$ and $27^{\circ} \mathrm{S}$ latitude (Figure 2). This is the southern-most limit of Neotropical montane forest (Hueck 1978). The Southern Yungas occurs primarily within an elevational zone of $700-2,700 \mathrm{~m}$ (Cabrera and Willink 1980). On the east it is bordered by the Chaco ecoregion. In Bolivia, the Southern Yungas extends from Santa Cruz Department through Chuquisaca and Tarija departments to the Bolivian border with Argentina to the south, covering an area $\sim 530 \mathrm{~km}$ long from north to south and $70 \mathrm{~km}$ wide (Rivera et al. 2010). In Argentina, the Southern Yungas extends $700 \mathrm{~km}$ from the Bolivian border south in an $\sim 50-\mathrm{km}$ wide swath that includes portions of Salta, Jujuy, Tucumán, and Catamarca provinces (Brown et al. 2009). The total extent of the Southern Yungas is $110,122 \mathrm{~km}^{2}$.

The elevational gradient within the Southern Yungas has fostered the development of 3 distinct habitat types, each with unique climatic, phytogeographic, and hydrographic characteristics: piedmont, montane, and cloud forest (Cabrera 1976, Bobba and Hernández 2005). Piedmont, at the lowest elevation $(400-900 \mathrm{~m})$, contains 113 tree species, of which $\sim 70 \%$ are semideciduous (Brown et al. 2001). Dominant tree species are Calycophyllum multiflorum, Phyllostylon rhamnoides, Tabebuia avellanedae, and Anadenanthera colubrina (Brown et al. 2001). Piedmont experiences the greatest seasonal variation in rainfall, with rains concentrated from November to March. Annual mean rainfall is $800-1,000 \mathrm{~mm}$, and annual mean temperature is $18-20^{\circ} \mathrm{C}$ (Mendoza 2005). Almost 90\% of piedmont forest has been converted to agriculture, and many remnants are unsustainably harvested (Brown and Malizia 2004). Montane forest (900-1,500 m elevation) has similar tree species diversity (118 species). Dominant tree species are Cinnamomum porphyria, Tipuana tipu, Cedrela lilloi, and several species of Myrtaceae. Montane forest has a mean annual rainfall of $1,200 \mathrm{~mm}$ and an annual mean temperature of $10-18^{\circ} \mathrm{C}$ (Mendoza 2005). 
A

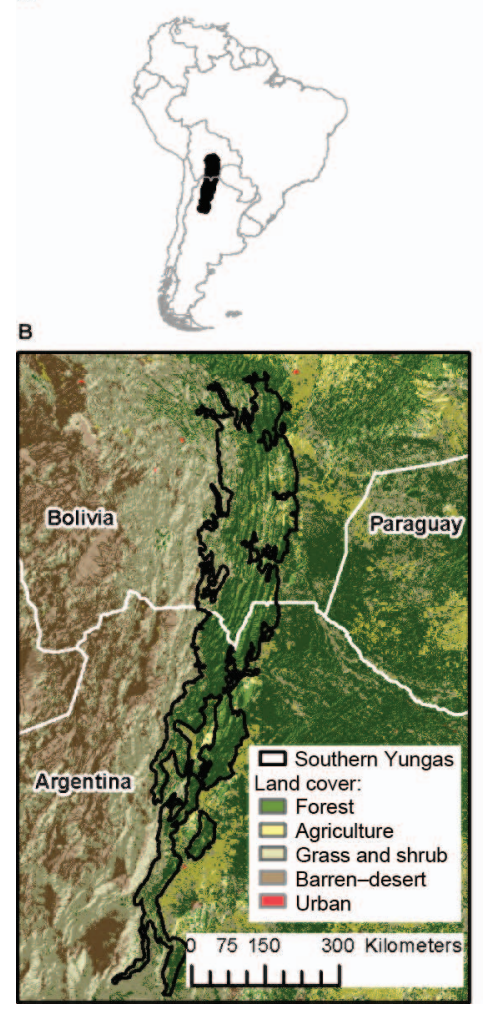

c

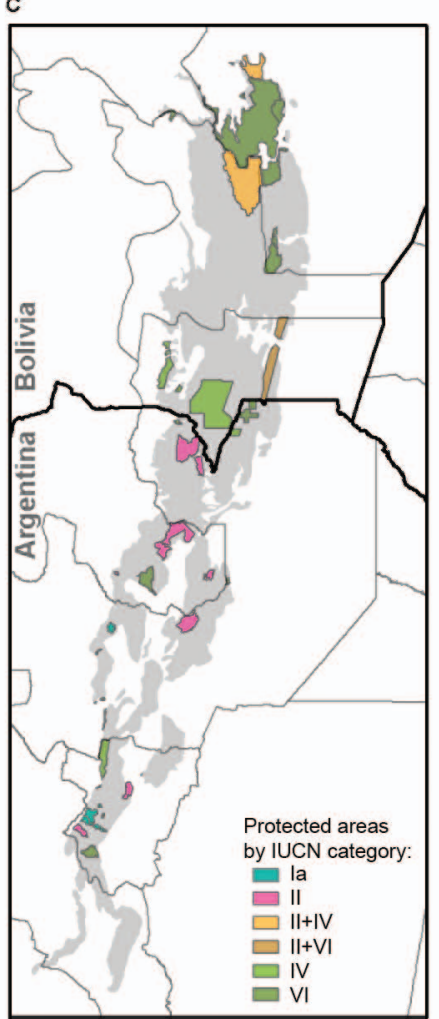

D

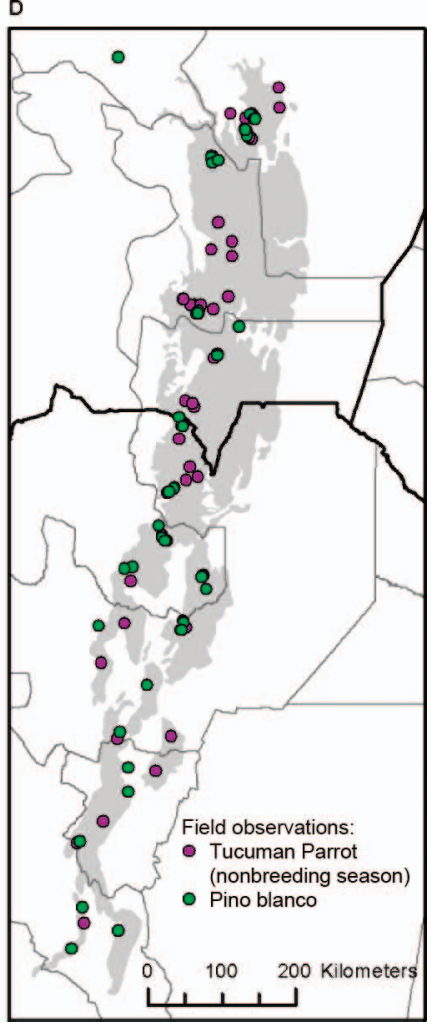

FIGURE 2. Protected areas of the Southern Yungas, and locations of Tucuman Parrots and pino blanco. The Southern Yungas ecoregion within (A) South America, and (B) in the context of other dominant land cover types that surround it in southern Bolivia and northwestern Argentina. (C) Protected areas categorized by their management goals (la $=$ Strict Nature Reserve, II = National Park, IV = Habitat or Species Management Area, VI = Protected Area with sustainable use of natural resources). (D) Occurrence data for Tucuman Parrots and pino blanco used in habitat suitability models.

Montane forest is under intensive logging pressure. The practice of releasing free-ranging cattle to graze also is common in montane forest. Cloud forest $(1,500-2,700 \mathrm{~m}$ elevation) has lower tree diversity (54 species) and is dominated by Podocarpus parlatorei, Alnus acuminata, Ilex argentina, Juglans australis, and Prunus tucumanensis. Annual precipitation ranges between 600 and $1,200 \mathrm{~mm}$; annual mean temperature is $12-18^{\circ} \mathrm{C}$ (Mendoza 2005). Cloud forest habitat is generally the least degraded because of its inaccessibility, but logging and periodic burning to promote grasses both occur.

The Tucuman Parrot breeds in cloud forests of the Southern Yungas but its geographic range is not fully known, especially in Bolivia where minimal infrastructure and steep topography in remote areas make access and surveys difficult (Rivera et al. 2010). Reproduction by Tucuman Parrots is thought to be limited by the availability of suitable nest cavities and the presence of mature (seed-producing) pino blanco trees in sufficient abundance to ensure adequate food for nestlings and juveniles (Rivera 2011, Rivera et al. 2012). These habitat elements are not uniformly distributed in Southern Yungas forest and are being affected by both long-term climatic factors and recent anthropogenic stressors. Since the Pleistocene epoch, pino blanco distribution appears to have contracted westward and upward in elevation, and to have become increasingly fragmented (Quiroga et al. 2012). Pino blanco is currently listed as 'Near Threatened' (IUCN 2014), and historic logging is thought to have contributed to its past loss from an estimated 30\% of its former range (Quiroga and Gardner 2013). Slashand-burn agriculture also may have contributed to the decline of this species in Bolivia (L. Rivera personal observation). Pino blanco is also currently listed in Appendix 1 of the Convention on International Trade in Endangered Species of Wild Fauna and Flora (CITES 2015), which bans international trade but not domestic logging.

During the nonbreeding season (May-September), cloud forest offers virtually no food resources for Tucuman Parrots (Rivera 2011). During this period Tucuman Parrots primarily use lower-elevation piedmont forest, where temperatures are more moderate than in cloud forest (Mendoza 2005). Large flocks roost in piedmont and forage primarily on leguminous seeds of Acacia visco and Parapiptadenia excelsa (Rivera 2011). 


\section{Spatial Data}

We modeled the current distribution of Tucuman Parrot nonbreeding habitat and of pino blanco (as a surrogate for breeding habitat) in Southern Yungas forest using a combination of observational data, climatic variables, and land-cover variables. We used a digital map of the limits of the Southern Yungas from Lizárraga et al. (2012) to define our study area. While a finer-scale delineation of the Bolivian forest types exists (Ibisch and Mérida 2008), the Lizárraga et al. (2012) map is based on consistent methodology for defining forest types in both countries, which was a requirement for our analysis. Data on Tucuman Parrot distribution were obtained from 2003 to 2009 in Argentina and from 2006 to 2011 in Bolivia (Rivera et al. 2007, 2010, 2012, Rivera 2011, Rojas Llanos 2012). Nonbreeding season surveys were conducted using walking surveys or by driving slowly along secondary roads for 6-12 hr, partitioned among two 3-hr observation periods, 1 beginning at dawn and 1 ending at dusk. The surveys were conducted at known historical locations of Tucuman Parrots in Argentina (20 sites) and Bolivia (18 sites). We included observations of parrots in the nonbreeding season from 50 unique locations in our analysis, each no closer than $1.7 \mathrm{~km}$ to adjacent locations. During the nesting season (November-March), daily searches for active nests were conducted and suitable cavities were inspected. Data on the locations of mature pino blanco stands were collected over the same period and were supplemented with data from Quiroga et al. (2012) for a total of 47 unique observations. Both datasets reflect the latitudinal and longitudinal breadth of the species' ranges (Figure 2).

We obtained climatic variables representing current conditions (1950-2000) mapped at $1 \mathrm{~km}$ resolution from the WorldClim database (Hijmans et al. 2005). From the total set of available bioclimatic variables (BIOCLIM), we selected 8 variables to represent means, seasonality, and extremes of climatic data, while minimizing strongly correlated variables (Bateman et al. 2012). Our variable set included annual precipitation $\left(\mathrm{mm} ; \mathrm{BIO}_{12}\right)$ and annual mean temperature $\left({ }^{\circ} \mathrm{C} ; \mathrm{BIO}_{1}\right)$, seasonality data for precipitation $\left(\mathrm{CV} ; \mathrm{BIO}_{15}\right)$ and temperature $\left(\mathrm{SD} * 100 ; \mathrm{BIO}_{4}\right)$, and extremes data for precipitation of the wettest quarter $(\mathrm{mm}$; $\left.\mathrm{BIO}_{16}\right)$, precipitation of the driest quarter $\left(\mathrm{mm} ; \mathrm{BIO}_{17}\right)$, maximum temperature of the warmest month $\left({ }^{\circ} \mathrm{C} ; \mathrm{BIO}_{5}\right)$, and minimum temperature of the coldest month $\left({ }^{\circ} \mathrm{C}\right.$; $\left.\mathrm{BIO}_{6}\right)$. Some of these variables were strongly correlated (e.g., temperature seasonality and precipitation seasonality; Appendix Table 4), but we retained them in the model because the nonparametric methods included in 'biomod2' (see below) are not affected by collinearity (Elith et al. 2011), and because we were mainly concerned with the final predicted suitability map rather than with identification of the most important variables.
We obtained forest land-cover data from the Global Land Cover 2000 database (http://www.eea.europa.eu/ data-and-maps/data/global-land-cover-2000-europe), which provides land-cover information at $1-\mathrm{km}$ resolution based on satellite data acquired by the VEGETATION instrument on board the SPOT 4 satellite, and reflects conditions ca. 2000. We extracted forest cover from the South American broad land-cover classification scheme, which includes forests, shrublands, grasslands, agricultural lands, barren surfaces, and water, ice, and snow (Eva et al. 2002). Because Tucuman Parrots require forest habitat, we calculated the proportion of forested pixels within a $5 \mathrm{~km}$ $\times 5 \mathrm{~km}$ window around each grid cell as an index of landcover context within the surrounding landscape. We obtained data on the distribution of protected areas in the Bolivian and Argentine portions of the study area from the Bolivian Natural Resource Digital Center (http:// cdrnbolivia.org/index_en.htm) and Lizárraga et al. (2012). Protected areas are categorized according to the primary management goals $(\mathrm{Ia}=$ strict nature protection; II = National Parks, where protection and education are the goals; IV = areas set aside for particular species or habitat types; and VI = sites permitting low-level extractive activities; Dudley 2008, IUCN 2014). We obtained information on the locations of recent sites of Tucuman Parrot nestling poaching from Rivera et al. (2010) and Rojas Llanos (2012).

\section{Modeling Approach}

We modeled potential suitable habitat (i.e. sites where the environmental conditions can or do support parrot habitat), some of which may not yet be known. We developed 2 distribution models based on climatic and forest-cover variables, 1 for nonbreeding season Tucuman Parrot habitat, and 1 for breeding season habitat using pino blanco as our proxy for suitable nesting habitat. We used species distribution models (SDMs) in R 2.1.15 ( $\mathrm{R}$ Development Core Team 2014) with package biomod2, a platform for ensemble species distribution modeling (Thuiller et al. 2009). Package biomod 2 provides several different SDM modeling algorithms, including Artificial Neural Networks (ANN), Classification and Regression Trees (CTA), Flexible Discrimination Analysis (FDA), Generalized Additive Models (GAM), Generalized Linear Models (GLM), Generalized Boosted Models (GBM), Multivariate Adaptive Regression Splines (MARS), Surface Range Envelope (SRE), Boosted Regression Trees (BRT), Random Forest (RF) and Maximum Entropy (MaxEnt). For detailed information on each of the modeling algorithms, see Phillips et al. (2006) and Thuiller et al. (2009). We used all 10 available algorithms to generate distribution models, and then selected the 4 top-performing models to carry out ensemble modeling. We used the default parameters defined by biomod2 for all 10 modeling algorithms. The 
modeling algorithms require binary or background data, so we generated pseudoabsences from within a 100-km buffer of the study area (VanDerWal et al. 2009, Bateman et al. 2012). For each model run, we conducted 2 model replicates of separate pseudoabsences, each chosen at random to obtain the most reliable distribution of model outputs (Barbet-Massin et al. 2012). For both models we generated 500 pseudoabsence background points, which was $\sim 10$ times the number of occurrence records (Martínez-Freiría et al. [2013], as suggested in Thuiller et al. [2009]). During the calibration process, we gave equal weighting to presence data and pseudoabsence data (i.e. prevalence $=0.5$ ).

To provide an unbiased measure of model performance and obtain standard errors for evaluation metrics (Pearce and Ferrier 2000), we conducted a 10-fold cross-validation (Elith et al. 2011, Bateman et al. 2012) with a 90\%:10\% split of presence data used for training and testing, respectively. For each modeling algorithm, we used 10-fold crossvalidation on the 2 pseudoabsence replicates, for a total of 20 replicates each. To ensure that all replicates were comparable, we rescaled each replicate within biomod2 using a binomial GLM (Thuiller et al. 2009, MartínezFreiría et al. 2013). We used Area Under the Curve ROC (receiver operating characteristic curve; AUC) values of the test models to evaluate the model performance of all 10 algorithms, and initially considered values above 0.7 to be indicative of useful models (Elith et al. 2006). We selected the 4 top-performing models of both breeding and nonbreeding habitat post hoc, and then calculated their unweighted average of the predicted distribution (i.e. the per grid cell average) to generate a consensus model of current conditions (Araújo and New 2007). In this approach, uncertainties from individual models contribute less, and areas of consensus among models contribute more, to the final product (Araújo and New 2007). AUC values from the cross-validation (for 2 pseudoabsence replicates; testing AUC) and training models are shown in Appendix Table 5.

In order to determine the extent of suitable habitat, it is necessary to transform the continuous predictions of habitat suitability from biomod2 into binary maps of habitat vs. nonhabitat. To do this we used a 2 -step process. First, we optimized for the threshold that maximized the percentage of presences and absences predicted correctly in the evaluation data, from the AUC plots (Thuiller 2004, Liu et al. 2005). Then we inspected the resulting suitable habitat maps visually, and, finding that they omitted a small number of known important locations of the Tucuman Parrot (potentially due to correlation among temperature variables used in the models), we relaxed the suitable vs. unsuitable threshold slightly to 0.5. This resulted in models that better fit the known distribution of breeding and nonbreeding habitat, and gave us confidence that the model would identify potential suitable habitat in areas that had not been surveyed.

To determine the degree of effectiveness of protection of breeding and nonbreeding habitat for the Tucuman Parrot, we calculated the areal extent of currently protected areas within the entire Southern Yungas ecoregion according to their level of protection as classified by IUCN category (Dudley 2008). We then estimated the proportions of suitable Tucuman Parrot nonbreeding and breeding habitat that occurred within these categories, in total and by country. To make these estimates we intersected, in turn, the map of the Southern Yungas ecoregion and the presence-absence maps of Tucuman Parrot potential nonbreeding and breeding habitat with maps of 36 protected areas.

We estimated representation targets (i.e. goals for areal extent of protected areas) for each of 3 habitat categories: the entire Southern Yungas, Tucuman Parrot nonbreeding habitat, and Tucuman Parrot breeding habitat. To do this we followed Rodrigues et al. (2004), who recommended that targets be determined as a varying proportion of the habitat to be protected, dependent on its areal extent. We set the target to $10 \%$ if the habitat extent was $\geq 250,000 \mathrm{~km}^{2}$ and to $100 \%$ if the habitat extent was $\leq 1,000 \mathrm{~km}^{2}$. We then interpolated between these 2 extremes using the equation:

$$
y=-0.1631 \ln (x)+2.1131,
$$

where $y$ is the representation target (proportion) and $x$ is the areal extent of the habitat category in $\mathrm{km}^{2}$. In order to understand how vulnerability to poaching is related to habitat characteristics, we created a $5 \mathrm{~km}$ buffer around each known poaching site and calculated the amount of forest cover, breeding habitat, and nonbreeding habitat within the buffer. Poaching site locations are all centered on forest access points (i.e. villages, roads, or forest edge). We chose a $5 \mathrm{~km}$ distance because we estimated that sites this close do not present logistical hurdles for potential poachers to reach on foot.

\section{RESULTS}

Ensemble models of both Tucuman Parrot nonbreeding $(\mathrm{AUC}=0.977 \pm 0.201 \mathrm{SD})$ and breeding habitat $(\mathrm{AUC}=$ $0.984 \pm 0.011$ SD) performed well. The FDA, RF, MaxEnt, and GBM frameworks produced the top-performing models for both types of habitat (Appendix Table 5). Predicted suitability of both Tucuman Parrot nonbreeding and breeding habitat was high where the abundance of parrots was known to be high (Figure 3), lending further support to our modeled habitat suitability distributions.

Our models indicated that conditions suitable for supporting Tucuman Parrot habitat were distributed across the entire north-south gradient of the Southern 

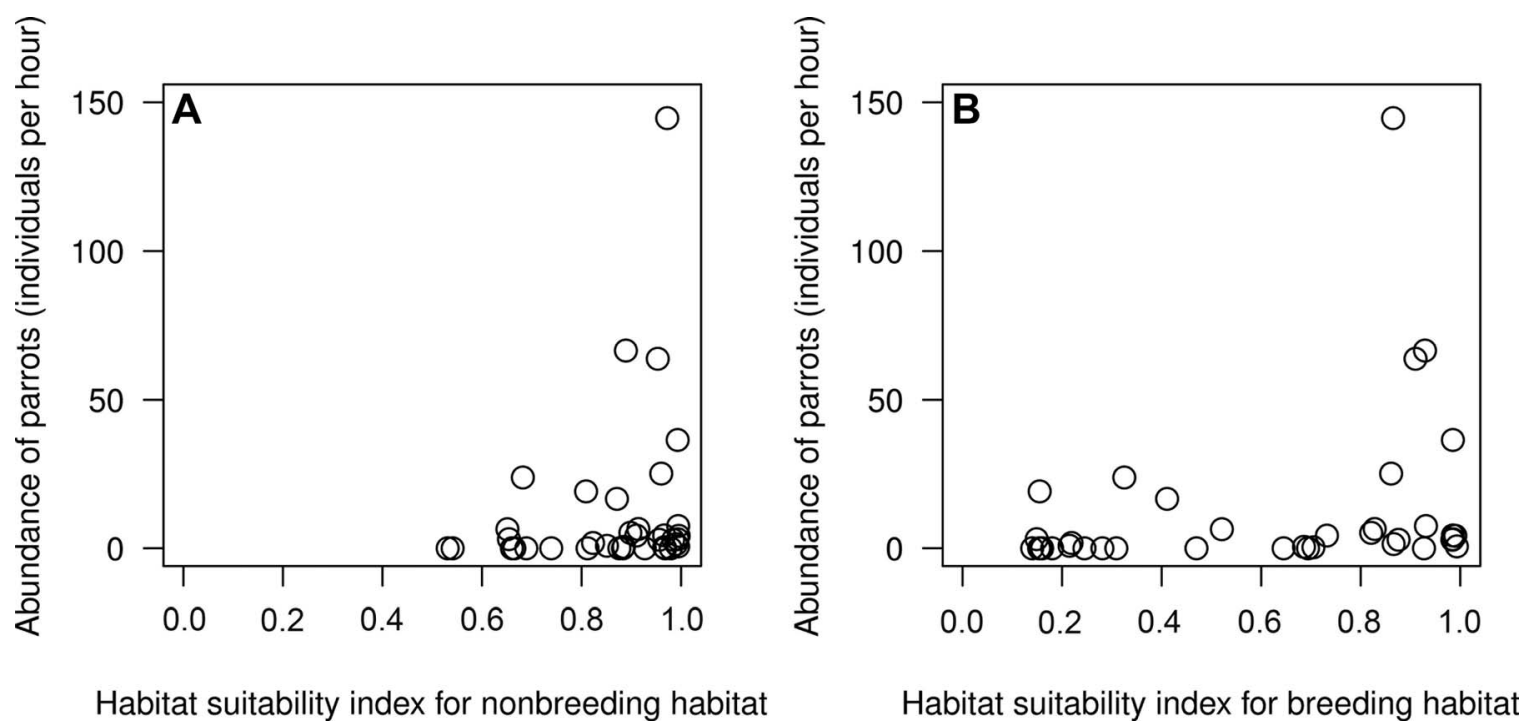

FIGURE 3. Maximum number of Tucuman Parrot individuals recorded in the field in the Southern Yungas ecoregion, related to the suitability of (A) nonbreeding habitat and (B) breeding habitat. Abundance data are from Rivera et al. (2007, 2010). An outlier datum of 4,147 individuals and habitat suitability value $>0.9$ for both breeding and nonbreeding habitat is not included on the graphs.

Yungas, in agreement with field observations of the species over the past $20 \mathrm{yr}$ (Figure 4). Not surprisingly, the great majority of Tucuman Parrot potential breeding habitat (i.e. potential pino blanco habitat, our proxy for breeding habitat) fell within the boundaries of potential nonbreeding habitat (87\% overlap in Argentina, and 98\% overlap in Bolivia). However, less than half of the Southern Yungas ( $\sim 6,000 \mathrm{~km}^{2} ; 42 \%$ ) was predicted to provide suitable nonbreeding habitat, with slightly more occurring in Bolivia $\left(\sim 26,000 \mathrm{~km}^{2}\right)$ than in Argentina $\left(\sim 20,000 \mathrm{~km}^{2}\right.$; Table 1).

Potential breeding habitat was substantially more limited than nonbreeding habitat (Figure 4); our models indicated that the environmental conditions that could support breeding habitat were found in only $\sim 21,000 \mathrm{~km}^{2}$, or 19\%, of the Southern Yungas (Table 1). Further, this potential breeding habitat was not evenly distributed between the 2 countries: About 3 times as much breeding habitat was found in Argentina $\left(\sim 15,400 \mathrm{~km}^{2}\right)$ as in Bolivia $\left(\sim 5,600 \mathrm{~km}^{2}\right)$. In Bolivia, potential breeding habitat existed only in very narrow belts and disjunct patches along ridgetops, whereas in Argentina potential breeding habitat patches were larger, with a more regular shape.

In Argentina, 23 protected areas overlap the Southern Yungas, and in Bolivia there are 13 overlapping areas (Figure 2). In total, $\sim 17 \%$ of the Southern Yungas ecoregion, or $18,142 \mathrm{~km}^{2}$, has legal protection (Table 2). The extent of protected Southern Yungas in Bolivia is 3 times larger than in Argentina $\left(\sim 14,000 \mathrm{~km}^{2}\right.$ vs. $\sim 4,300$ $\mathrm{km}^{2}$ ). This means that $24 \%$ of Bolivia's, but only $8 \%$ of Argentina's, Southern Yungas enjoys protected status. Taking into account the nature of protected status, only $\sim 6 \%$ of the ecoregion as a whole is under strict protection, with an additional 10\% protected but permitting some traditional uses. While Bolivia has no IUCN category Ia strict nature reserves, 3 Bolivian protected areas are under relatively strict protection as combinations of National Parks and habitat or species management areas (categories II plus IV) or National Parks and sustainable use areas (categories II plus VI), together encompassing 4,061 km². The remainder of Bolivian protected areas $\left(9,741 \mathrm{~km}^{2}\right)$ allow some traditional resource extraction. In Argentina, $\sim 2,800 \mathrm{~km}^{2}$, or $\sim 6 \%$ of the Southern Yungas in that country, are within protected areas that have strict nature values as their primary goals (IUCN categories I and II), while the remaining $3 \%$ permit low-level traditional extractive uses.

Our calculations of habitat conservation representation targets followed the recommendations of Rodrigues et al. (2004) and suggested that $\sim 22 \%$ of the Southern Yungas ecoregion, $36 \%$ of the nonbreeding habitat, and $49 \%$ of the much more restricted breeding habitat should be in protected status (Table 1). The shortfall (i.e. the deficit) in the amount of the Southern Yungas ecoregion that is protected, relative to its target, is only $6,170 \mathrm{~km}^{2}$, just $25 \%$ below the recommended areal extent in protected status. The existing protected network contains $11,880 \mathrm{~km}^{2}$ of nonbreeding habitat, which is also relatively close to ( $\sim 71 \%$ of) the target of $\sim 17,000 \mathrm{~km}^{2}$. However, the picture is very different for potential breeding habitat, which totals only about $21,000 \mathrm{~km}^{2}$ and is much smaller in extent than the potential nonbreeding habitat and the Southern Yungas as a whole (Table 1). Because of this smaller area, the representation target for breeding habitat is larger, at $49 \%$. 

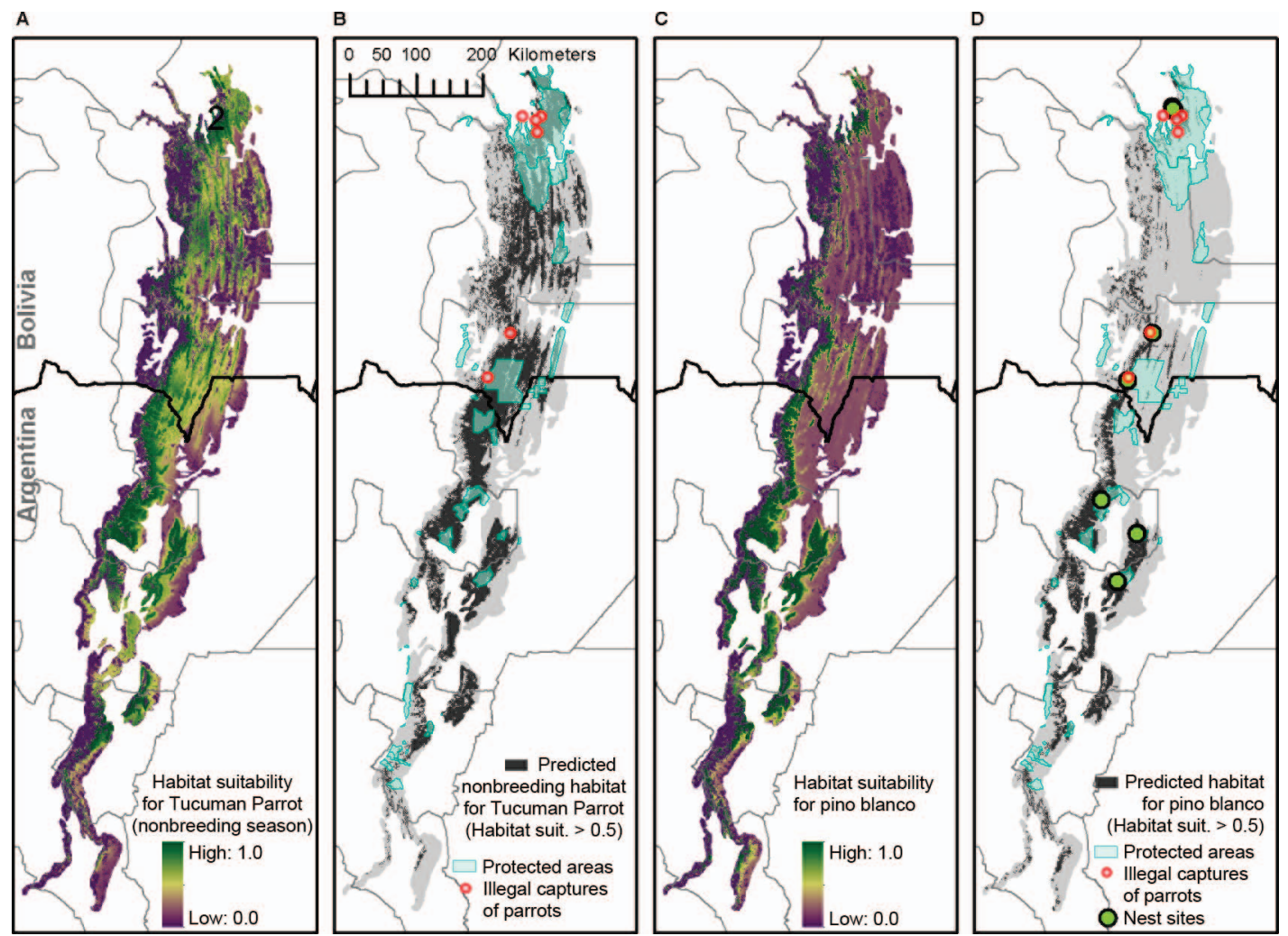

FIGURE 4. (A) Habitat suitability map for Tucuman Parrot nonbreeding habitat within the Southern Yungas ecoregion, and (B) areas of predicted nonbreeding habitat relative to known parrot poaching sites and protected areas. (C) Habitat suitability map for Tucuman Parrot breeding habitat as represented by the predicted occurrence of pino blanco, the seeds of which are a critical food for Tucuman Parrot nestlings, and (D) areas of predicted breeding habitat relative to known locations of Tucuman Parrot poaching sites, known nest sites, and protected area locations.

Yet only $15 \%\left(3,134 \mathrm{~km}^{2}\right)$ of the breeding habitat is currently within protected areas, and only $\sim 6 \%$, all in Argentina, is strictly protected (Table 2). Thus, the shortfall of protected breeding habitat across the entire
Southern Yungas is $7,155 \mathrm{~km}^{2}$, or $70 \%$ of the habitat conservation target of $10,288 \mathrm{~km}^{2}$.

We also estimated habitat conservation targets within each country separately to better match the scale of

TABLE 1. The current land area, the target proportion that should have protected status, the amount currently protected, and the additional extent needed to bridge this gap (shortfall), for the Southern Yungas ecoregion and for nonbreeding and breeding habitat of the Tucuman Parrot, within the entire Southern Yungas ecoregion and by individual country.

\begin{tabular}{|c|c|c|c|}
\hline & S. Yungas & Argentina & Bolivia \\
\hline \multicolumn{4}{|l|}{ Southern Yungas ecoregion } \\
\hline Total extent $\left(\mathrm{km}^{2}\right)$ & 110,122 & 51,683 & 58,438 \\
\hline Target proportion for protection & 0.22 & 0.34 & 0.32 \\
\hline Currently protected $\left(\mathrm{km}^{2}\right)$ & 18,142 & 4,340 & 13,802 \\
\hline Shortfall $\left(\mathrm{km}^{2}\right)$ & 6,170 & 13,443 & 5,136 \\
\hline \multicolumn{4}{|c|}{ Tucuman Parrot potential nonbreeding habitat } \\
\hline Total extent $\left(\mathrm{km}^{2}\right)$ & 46,263 & 20,115 & 26,148 \\
\hline Target proportion for protection & 0.36 & 0.50 & 0.46 \\
\hline Currently protected $\left(\mathrm{km}^{2}\right)$ & 11,880 & 2,721 & 9,163 \\
\hline Shortfall $\left(\mathrm{km}^{2}\right)$ & 4,873 & 7,294 & 2,739 \\
\hline \multicolumn{4}{|c|}{ Tucuman Parrot potential breeding habitat } \\
\hline Total extent $\left(\mathrm{km}^{2}\right)$ & 20,938 & 15,386 & 5,553 \\
\hline Target proportion for protection & 0.49 & 0.54 & 0.71 \\
\hline Currently protected $\left(\mathrm{km}^{2}\right)$ & 3,134 & 1,525 & 1,611 \\
\hline Shortfall $\left(\mathrm{km}^{2}\right)$ & 7,155 & 6,808 & 2,319 \\
\hline
\end{tabular}


TABLE 2. Areal extents $\left(\mathrm{km}^{2}\right)$ and percentages (\%) of the Southern Yungas ecoregion, and of Tucuman Parrot nonbreeding and breeding habitats in the entire ecoregion, Argentina, and Bolivia, that occur within protected areas, according to IUCN protection categories.

\begin{tabular}{|c|c|c|c|c|c|c|}
\hline \multirow[b]{2}{*}{ IUCN category } & \multicolumn{2}{|c|}{$\begin{array}{l}\text { Southern } \\
\text { Yungas }\end{array}$} & \multicolumn{2}{|c|}{ Argentina } & \multicolumn{2}{|c|}{ Bolivia } \\
\hline & $\mathrm{km}^{2}$ & $\%$ & $\mathrm{~km}^{2}$ & $\%$ & $\mathrm{~km}^{2}$ & $\%$ \\
\hline \multicolumn{7}{|l|}{ Entire ecoregion } \\
\hline la & 440 & 0.4 & 440 & 0.9 & 0 & 0.0 \\
\hline ॥ & 2,392 & 2.2 & 2,392 & 4.6 & 0 & 0.0 \\
\hline $\mathrm{II}+\mathrm{IV}, \mathrm{II}+\mathrm{VI}$ & 4,061 & 3.7 & 0 & 0.0 & 4,061 & 6.9 \\
\hline IV & 3,528 & 3.2 & 579 & 1.1 & 2,949 & 5.0 \\
\hline VI & 7,721 & 7.0 & 930 & 1.8 & 6,791 & 11.6 \\
\hline Total & 18,142 & 16.5 & 4,340 & 8.4 & 13,802 & 23.6 \\
\hline \multicolumn{7}{|c|}{ Nonbreeding habitat } \\
\hline la & 116 & 0.3 & 116 & 0.6 & 0 & 0.0 \\
\hline$\|$ & 2,056 & 4.4 & 2,056 & 10.2 & 0 & 0.0 \\
\hline $\mathrm{II}+\mathrm{IV}, \mathrm{II}+\mathrm{VI}$ & 2,555 & 5.5 & 0 & 0.0 & 2,554 & 9.8 \\
\hline IV & 2,263 & 4.9 & 31 & 0.2 & 2,233 & 8.5 \\
\hline VI & 4,889 & 10.6 & 517 & 2.6 & 4,376 & 16.7 \\
\hline Total & 11,880 & 25.7 & 2,721 & 13.5 & 9,163 & 35.0 \\
\hline \multicolumn{7}{|l|}{ Breeding habitat } \\
\hline la & 130 & 0.6 & 130 & 0.8 & 0 & 0.0 \\
\hline II & 1,034 & 4.9 & 1,034 & 6.7 & 0 & 0.0 \\
\hline $\mathrm{II}+\mathrm{IV}, \mathrm{II}+\mathrm{VI}$ & 276 & 1.3 & 0 & 0.0 & 276 & 5.0 \\
\hline IV & 313 & 1.5 & 19 & 0.1 & 295 & 5.3 \\
\hline VI & 1,380 & 6.6 & 341 & 2.2 & 1,040 & 18.7 \\
\hline Total & 3,134 & 15.0 & 1,525 & 9.9 & 1,611 & 29.0 \\
\hline
\end{tabular}

conservation management. Because the areas within each country are smaller, representation targets are proportionally higher, especially for potential breeding habitat. For the Southern Yungas, the protection target is $34 \%$ in Argentina and $32 \%$ in Bolivia (Table 1). To ensure protection of adequate breeding habitat, the representation target in Argentina is 54\%, and in Bolivia is 71\%, reflecting the relatively small amount of potential breeding habitat in Bolivia $\left(\sim 5,553 \mathrm{~km}^{2}\right)$.

There are 6 sites where poaching of the Tucuman Parrot is known to occur, all of them in Bolivia (Figure 4, Table 3). Four of these sites occur within designated protected areas that are in IUCN categories IV and VI. The area within 5 $\mathrm{km}$ of each of these sites is $79 \mathrm{~km}^{2}$. The proportion of this area that was predicted to be in breeding habitat, and that we thus estimated to be at high risk of poaching activity, ranged from under $3 \%$ (just under $2 \mathrm{~km}^{2}$, at Valle Grande, a site without protected status) to $70 \%\left(53-55 \mathrm{~km}^{2}\right.$ at Tariquia Flora and Fauna National Reserve and San Lorenzo, and $53 \mathrm{~km}^{2}$ at a site without protected area status, Narvaez, located in Tarija Department). We estimated that, in total, $170 \mathrm{~km}^{2}$ of breeding habitat that was located within protected areas was at high risk for illegal parrot capture. Outside protected areas, any nests occurring within an additional $57 \mathrm{~km}^{2}$ could be highly vulnerable to poaching.
TABLE 3. Protection status and potential breeding habitat at risk of poaching at 6 sites, all in Bolivia, where Tucuman Parrot nestlings are known to have been removed from nests. Status denotes whether the site is inside or outside a protected area and the level of IUCN protection. The area at risk includes potential breeding habitat within a $5 \mathrm{~km}$ radius around each poaching site.

\begin{tabular}{llc}
\hline Site name & \multicolumn{1}{c}{$\begin{array}{c}\text { Protection } \\
\text { status }\end{array}$} & $\begin{array}{c}\text { Extent of potential } \\
\text { breeding habitat at risk }\end{array}$ \\
\hline Narvaez ${ }^{\text {a }}$ & outside & $55 \mathrm{~km}^{2}$ \\
Valle Grande $^{2}$ & outside & $2 \mathrm{~km}^{2}$ \\
Postrervalle & inside; IUCN VI & $25 \mathrm{~km}^{2}$ \\
San Lorenzo $^{\text {b }}$ & inside; IUCN VI & $55 \mathrm{~km}^{2}$ \\
Potrerillos $^{\text {b }}$ & inside; IUCN VI & $37 \mathrm{~km}^{2}$ \\
Tariquia FFNR $^{\text {c }}$ & inside; IUCN IV & $53 \mathrm{~km}^{2}$ \\
\hline
\end{tabular}

${ }^{a}$ In Tarija Department.

${ }^{\mathrm{b}}$ In Santa Cruz Department.

${ }^{\mathrm{C}}$ Flora and Fauna National Reserve.

\section{DISCUSSION}

Our goal was to assess the potential effectiveness of currently protected areas for the conservation of the Tucuman Parrot in the Southern Yungas. Based on the size of the ecoregion, the percentage recommended for Tucuman Parrot conservation (i.e. its representation target) is $22 \%$, and the actual amount under protection is $16 \%$. These percentages are reasonably close, so at first glance it seems that the Southern Yungas and the endemic Tucuman Parrot are fairly well represented in protected areas. However, the question of what constitutes adequate protection deserves closer scrutiny because critical needs for sustaining the parrot population, especially for breeding, require specific habitats that are not available throughout the ecoregion. Particularly alarming is the fact that, while the conservation representation target is to have $49 \%$ of potential breeding habitat in protected areas, just $15 \%$ enjoys any level of protection, and $<7 \%$ is strictly protected from uses such as single-tree harvest and cattle grazing (Table 2). Tree harvest has reduced availability of nest sites for cavity-nesting birds in the Southern Yungas (Cornelius et al. 2008, Politi et al. 2010). Thus, the representation target for breeding habitat certainly has not been met, and the adequacy of protection of areas classed below IUCN category II is unclear.

We modeled potential breeding habitat based on predicted pino blanco distribution, assuming that pino blanco seeds are essential for Tucuman Parrot reproduction. However, this metric may result in an overestimate of breeding habitat because models do not include information about pino blanco age structure. This matters because pino blanco trees don't bear seeds until they are $\sim 50$ yr old (Blendinger 2006). Further, nest trees (of any species) must be $>40 \mathrm{~cm}$ in diameter at breast height to provide suitable nesting cavities (Rivera 2011). These conditions are 
certainly not met in all areas where pino blanco trees occur, meaning that the current extent of potential breeding habitat may be even smaller than we predicted.

Inclusion in CITES Appendix 1 protects pino blanco trees from international trade, but not from domestic use (CITES 2015). In Argentina, pino blanco was intensively logged until the 1990s (Politi et al. 2009), and individual pino blanco trees are still logged for local uses (Politi et al. 2010). Our analysis was based on forest cover data from the year 2000, but in the decade ending in 2010, an estimated $1,730 \mathrm{~km}^{2}$ of Southern Yungas was deforested (Malizia et al. 2012), a statistic consistent with other recent estimates of Southern Yungas deforestation (e.g., Montenegro et al. 2012, Secretaría de Ambiente y Desarrollo Sustentable de la Nación 2012). Forest loss has occurred primarily in the piedmont (L. Rivera and N. Politi personal observation). In protected areas of IUCN categories IV and VI, as well as outside protected areas, single tree harvest, livestock grazing, and forage improvement activities all take place (L. Rivera and N. Politi personal observation), contributing to the degradation and loss of Southern Yungas forest. As forest cover is lost or degraded, the overall amount of available habitat declines, and the representation target should increase further. Tracking the amount of habitat that should be protected creates a management challenge that can be met through careful forest monitoring.

When contemplating conservation effectiveness, we also considered the distribution of breeding habitat between Argentina and Bolivia. Because 3 times more potential breeding habitat occurs in Argentina than in Bolivia, it could be argued that the responsibility for ensuring the maintenance of an adequate amount of this critical habitat type is 3 times greater for Argentina than for Bolivia. Under this logic, approximately three-quarters of the recommended $\sim 10,000 \mathrm{~km}^{2}$ of protected breeding habitat should fall within Argentina. Currently, each country harbors less than $1,600 \mathrm{~km}^{2}$ of protected breeding habitat. Thus, especially in Argentina, where land conversion is proceeding rapidly in the northern part of the country (Montenegro et al. 2012), the amount of protected breeding habitat needs to be increased by $\sim 5$ times to meet the representation target that maximizes the likelihood of Tucuman Parrot persistence.

The Southern Yungas ecoregion extends south to the provinces of Tucumán and Catamarca in Argentina, and our models suggest that suitable environmental conditions exist to support breeding and nonbreeding habitat there. Yet, efforts to locate the Tucuman Parrot in this southernmost extent, at sites where Wetmore (1926) and others recorded their presence historically, have been unsuccessful. Forest degradation is likely a strong contributing factor to the absence of parrots in these areas (Rivera et al. 2007). We do not reject the possibility that Tucuman Parrots may persist or use the southern-most Southern Yungas intermittently during the nonbreeding season. In fact, the discrepancy between predicted and actual habitat is useful for planning, as it highlights locations where targeted management, such as cattle exclusion and a moratorium on forest harvest (Politi et al. 2010), could be effectively undertaken to expand the distribution of habitat to its previously documented extent.

Our ensemble niche model predicted that potential suitable breeding habitat could occur in the northwestern part of the Southern Yungas (Cochabamba and Santa Cruz departments, and Amboró National Park), where, to our knowledge, no Tucuman Parrot surveys have been conducted. Pino blanco has been confirmed to grow in this area (Navarro and Maldonado 2002). This northwestern area should be prioritized for future field investigation, to determine whether Tucuman Parrot nesting or mature pino blanco foraging habitat occur there.

Development of suitable nesting conditions takes several decades, due to the need for both mature pino blanco trees for foraging and trees large enough to contain nest cavities. Therefore, we suggest that securing the protection of known nesting areas against tree harvest merits the highest priority. Expanding the protection of pino blanco habitat and ensuring that protection is sufficient to both maintain mature trees and facilitate the regeneration of young trees would also be beneficial. Providing incentives for landowners to ensure that some pino blanco habitat is consistently shielded from grazing and burning could facilitate tree regeneration. Further, governmental regulators should consider halting the local trade of this tree species.

These protective measures could provide habitat not only for Tucuman Parrots, but also for a broader group of species. Pino blanco provides food for other species of conservation concern, such as the Red-faced Guan (Penelope dabbenei), and common species such as the Band-tailed Pigeon (Patagioenas fasciata), Chiguanco Thrush (Turdus chiguanco), and Molina's hog-nosed skunk (Conepatus chinga; Fra et al. 2007). Pino blanco forests also are habitat for additional species with restricted ranges, including the Yellow-striped Brushfinch (Atlapetes citrinellus), White-browed Tapaculo (Scytalopus superciliaris), Slaty Elaenia (Elaenia strepera), Blue-capped Puffleg (Eriocnemis glaucopoides), and Rothschild's Swift (Cypseloides rothschildi; BirdLife International 2013).

Considering resource needs during each stage of the annual cycle may be necessary for the successful conservation not only of migratory species (Hostetler et al. 2015), but of resident species as well. For example, the endangered Hawaiian Goose (Branta sandvicensis) uses very different habitat types during the breeding and nonbreeding seasons (Leopold and Hess 2013), and explicit consideration of nesting, summer, and winter 
habitat is critical for habitat prioritization efforts for Greater Sage-Grouse (Centrocercus urophasianus), a species of conservation concern (Fedy et al. 2014). Nestlings of several species of conservation concern depend on specialized foods, including the critically endangered Ridgway's Hawk (Buteo ridgwayi), for which the nestling diet is primarily reptiles (Woolaver et al. 2013). The Blakiston's Fish-Owl (Bubo blakistoni) requires a combination of specialized nest sites and specialized diet for population persistence (Slaght et al. 2013), as do many Psittacidae in addition to the Tucuman Parrot. For example, the Scarlet Macaw (Ara macao; Renton 2006), Lilac-crowned Parrot (Amazona finschi; Renton and Salinas-Melgoza 1999), Red-crowned Parrot (Amazona viridigenalis; Enkerlin-Hoeflich and Hogan 1997), and Hyacinth Macaw (Anodorhynchus hyacinthinus; Birdlife International 2014) all have specialized nestling diets in addition to requiring cavities for nesting. Intrinsic habitat elements such as large cavity-bearing trees or food-bearing species are not typically mapped at the ecoregion scale, but can be maintained through directed management (Beaudry et al. 2010).

The largest protected areas, and the most inaccessible areas of Southern Yungas forest, are found in Bolivia. While in many large protected areas inaccessibility confers protection (Joppa et al. 2008), enforcement is also more challenging, and in the Southern Yungas these inaccessible areas are where Tucuman Parrot nest poaching occurs (Rivera et al. 2010, Rojas Llanos 2012). Capturing parrots has been illegal in Bolivia since 1999 (Herrera and Hennessey 2007), and, while poaching outside protected areas is a disturbing problem, poaching of Tucuman Parrots within protected areas gravely undermines the contribution of these protected areas to ensuring population persistence. Tucuman Parrots typically make one nesting effort per year (Rivera 2011). The proportion of the nesting population at a given site that is affected by poaching is unknown, but in other Amazona species up to $70 \%$ of nesting attempts have failed due to poaching (Wright et al. 2001), and the absence of at least 2 parrot species from substantial areas of suitable habitat in Mexico has been attributed to poaching (Marin-Togo et al. 2012). The attractiveness of Amazona parrots (Figure 5) is associated with high poaching pressure relative to less attractive genera (Tella and Hiraldo 2014). Anecdotal evidence of Tucuman Parrots kept as pets in villages in the vicinity of our 6 mapped known poaching sites (J. Tella personal communication) suggests that local customs and attitudes toward parrots are a challenge to the conservation of this species, as well as others in Bolivia (e.g., the Red-fronted Macaw [Ara rubrogenys]; Tella et al. 2013). The proximity of nest sites to areas of human activity, coupled with inadequate enforcement, are associated with high rates of nest poaching of the Scarlet Macaw in Belize

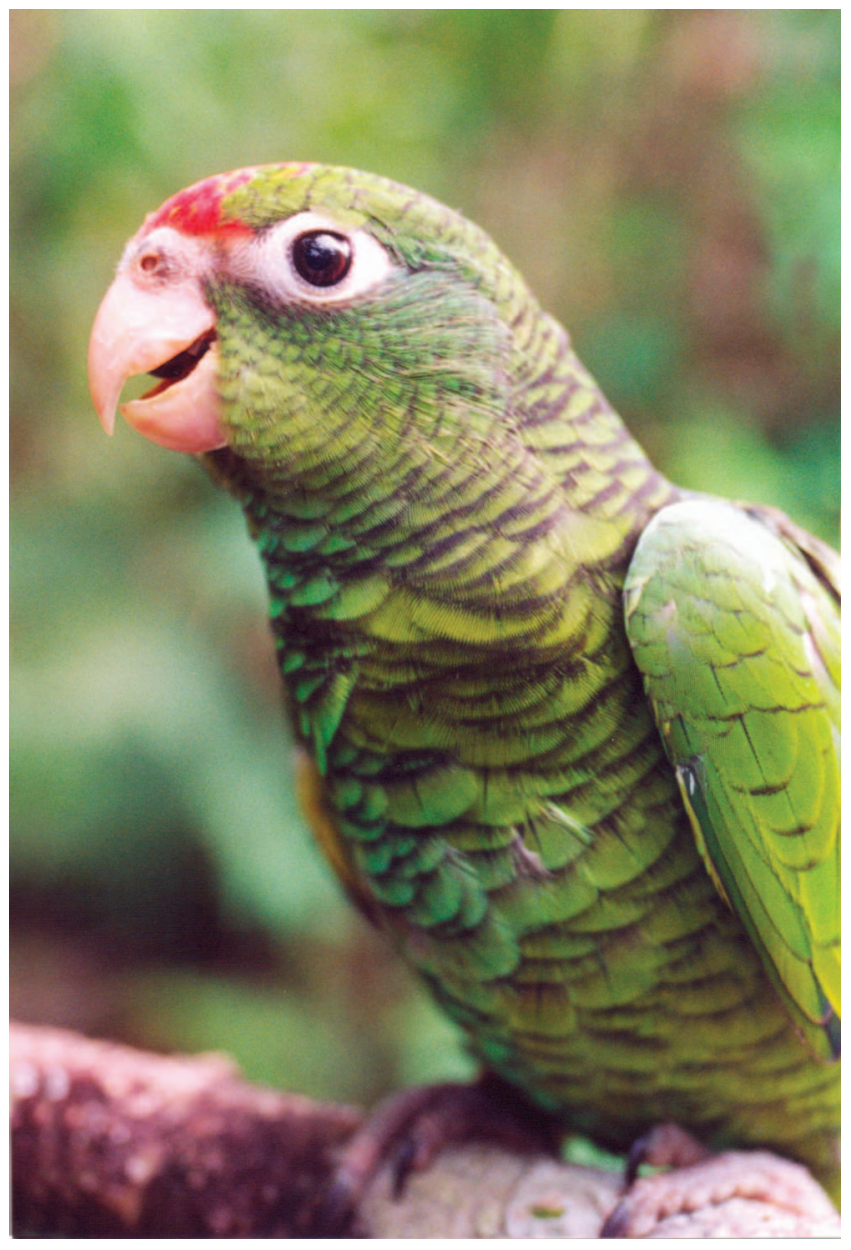

FIGURE 5. The Tucuman Parrot is vulnerable to poaching for the pet trade.

(Britt et al. 2014), and we suspect that unprotected Tucuman Parrot nests also experience high poaching rates in the vicinity of human activity. Strengthening the enforcement of existing laws by strategically applying greater effort toward detecting and halting illegal take in the vicinity of known poaching sites could increase the adequacy of protected areas in Bolivia. Educational efforts aimed at increasing pride in wild parrots and other charismatic wildlife, while discouraging their use as pets, is a strategy that has met with success locally in Argentina and Bolivia (http://www.cebio.org.ar/), and is a conservation strategy that could more broadly contribute to maintaining Tucuman Parrot population viability.

In summary, in Argentina, the most effective way to ensure Tucuman Parrot population persistence is to strategically add to the protected area, prioritizing: (1) areas of the Southern Yungas containing mature pino blanco, and (2) areas where pino blanco in earlier age classes can be protected to maturity. In Bolivia, where our models suggest potential nesting habitat is far less 
abundant, the challenge is to discourage poaching, through both education and enforcement of existing laws.

Our study highlights the fact that, for some species, effective conservation may require the presence and active management of one or more specific habitat elements or conditions, such as age-class structure. Representation targets for habitat conservation that are based solely on area may be inadequate for securing the population persistence of these species if important biological information is overlooked.

\section{ACKNOWLEDGMENTS}

We are grateful to L. Lizárraga and D. Rumíz for information on protected areas of Argentina and Bolivia, respectively; to R. Rojas Llanos and P. Montenegro for collaboration in Bolivia; and to V. C. Radeloff, J. Tella, and 2 anonymous reviewers for insightful comments that improved the manuscript.

Funding statement: This work was supported by the Conservation Leadership Programme, Loro Parque Fundación, Idea Wild, a Rufford Foundation Small Grant, the Whitley Fund for Nature, Wildlife Conservation Society, Overbrook Foundation, and by the University of WisconsinMadison. None of these funders had any influence on the content of the submitted or published manuscript. None of these funders required approval of the final manuscript to be published.

Ethics statement: We followed the Code of Ethics of the Ecological Society of America.

\section{LITERATURE CITED}

Araújo, M. B., and M. New (2007). Ensemble forecasting of species distributions. Trends in Ecology \& Evolution 22:42-47.

Barbet-Massin, M., F. Jiguet, C. H. Albert, and W. Thuiller (2012). Selecting pseudo-absences for species distribution models: How, where and how many? Methods in Ecology and Evolution 3:327-338.

Bateman, B. L., J. VanDerWal, S. E. Williams, and C. N. Johnson (2012). Biotic interactions influence the projected distribution of a specialist mammal under climate change. Diversity and Distributions 18:861-872.

Beaudry, F., A. M. Pidgeon, V. C. Radeloff, R. W. Howe, D. J. Madenoff, and G. A. Bartelt (2010). Modeling regional-scale habitat of forest birds when land management guidelines are needed but information is limited. Biological Conservation 143:1759-1769.

Beissinger, S. R. (2013). Trade of live wild birds: Potentials, principles, and practices of sustainable use. In Conservation of Exploited Species (J. D. Reynolds, G. M. Mace, K. H Redford, and J. G. Robinson, Editors). Cambridge University Press, Cambridge, UK. pp. 182-202.

Birdlife International (2013). IUCN Red List for Birds. http://www. birdlife.org

BirdLife International (2014). Anodorhynchus hyacinthinus. In The IUCN Red List of Threatened Species, version 2014.3. www. iucnredlist.org
Blendinger, P. G. (2006). El Pino del Cerro (Podocarpus parlatorei) como modelo de estudio para la conservación, ecología y biogeografía de los Bosques Montanos nublados de Yungas. Informe inédito. LIEY, Tucumán, Argentina.

Bobba, M. E., and C. M. Hernández (2005). Aspectos geográficos del Noroeste Argentino. In El clima del Noroeste Argentino (J. L. Minetti, Editor). Magna Press, Tucumán, Argentina. pp. 723.

Britt, C. R., R. G. Anleu, and M. J. Desmond (2014). Nest survival of a long-lived psittacid: Scarlet Macaws (Ara macao cyanoptera) in the Maya Biosphere Reserve of Guatemala and Chiquibul Forest of Belize. The Condor: Ornithological Applications 116: 265-276.

Brooks, T. M., M. E. Bakarr, T. Boucher, G. A. B. de Fonseca, C. Hilton-Taylor, J. M. Hoekstra, T. Moritz, S. Olivier, J. Parrish, R. L. Pressey, A. S. L. Rodrigues, et al. (2004). Coverage provided by the global protected area system: Is it enough? BioScience 54:1081-1091.

Brown, A. D., and L. R. Malizia (2004). Las Selvas Pedemontana de las Yungas: En el umbral de la extinción. Ciencia Hoy 14:5263.

Brown, A. D., P. G. Blendinger, T. Lomascolo, and P. Garcias Bes (Editors) (2009). Ecología, historia natural y conservación de la Selva Pedemontana de las Yungas Australes. Ediciones del Subtrópico, Center B. N. R. D. Biodiversidad, Tucumán, Argentina.

Brown, A. D., H. R. Grau, L. R. Malizia, and A. Grau (2001). Argentina. In Bosques nublados del Neotrópico (M. Kappelle and A. D. Brown, Editors). Instituto Nacional de Biodiversidad, San José, Costa Rica. pp. 623-659.

Bruner, A., R. Gullison, and A. Balmford (2004). Financial costs and shortfalls of managing and expanding protected area systems in developing countries. BioScience 54:1119-1126.

Cabrera, A. L. (1976). Regiones fitogeográficas Argentinas. In Enciclopedia Argentina de agricultura y jardinería. Tomo II. Fascículo 1. Acme, Buenos Aires, Argentina. pp. 1-85.

Cabrera, A. L., and A. Willink (1980). Biogeografía de América Latina. Organization of American States, Washington, DC, USA.

CITES (2015). Convention on International Trade in Endangered Species of Wild Fauna and Flora. http://www.cites.org/

Cornelius, C., K. Cockle, N. Politi, I. Berkunsky, L. Sandoval, V. Ojeda, L. Rivera, M. Hunter, and K. Martin (2008). Cavitynesting birds in Neotropical forests: Cavities as a potentially limiting resource. Ornitologia Neotropical 19:253-268.

Dudley, N. (Editor) (2008). Guidelines for Applying Protected Area Management Categories. IUCN, Gland, Switzerland.

Elith, J., C. H. Graham, R. P. Anderson, M. Dudík, A. Guisan, R. J. Hijmans, F. Huettmann, J. R. Leathwick, A. Lehmann, J. Li, L. G. Lohmann, et al. (2006). Novel methods improve prediction of species' distributions from occurrence data. Ecography 29: 129-151.

Elith, J., S. J. Phillips, T. Hastie, M. Dudík, Y. E. Chee, and C. J. Yates (2011). A statistical explanation of MaxEnt for ecologists. Diversity and Distributions 17:43-57.

Enkerlin-Hoeflich, E. C., and K. M. Hogan (1997). Red-crowned Parrot (Amazona viridigenalis). In The Birds of North America 292 (F. B. Gill and A. Poole, Editors). Academy of Natural Sciences, Philadelphia, PA, USA, and American Ornithologists' Union, Washington, DC, USA. 
Eva, H., E. E. De Miranda, C. M. Di Bella, V. Gond, O. Huber, M. Sgrenzaroli, S. Jones, A. Coutinho, A. Dorado, M. Guimarães, C. Elvidge, et al. (2002). A Vegetation Map of South America. European Commission Joint Research Centre EUR 20159 EN, Office for Official Publications of the European Communities, Luxembourg.

Fedy, B. C., K. E. Doherty, C. L. Aldridge, M. O'Donnell, J. L. Beck, B. Bedrosian, D. Gummer, M. J. Holloran, G. D. Johnson, N. W. Kaczor, C. P. Kirol, et al. (2014). Habitat prioritization across large landscapes, multiple seasons, and novel areas: An example using Greater Sage-Grouse in Wyoming. Wildlife Monographs 190:1-39.

Ferraro, P. J., M. M. Hanauer, D. A. Miteva, G. Javier CanavireBacarreza, S. K. Pattanayak, and K. R. E. Sims (2013). More strictly protected areas are not necessarily more protective: Evidence from Bolivia, Costa Rica, Indonesia, and Thailand. Environmental Research Letters 8:1-7.

Fjeldså, J., and N. Krabbe (1990). Birds of the High Andes: A Manual to the Birds of the Temperate Zone of the Andes and Patagonia, South America. Apollo Books, Copenhagen, Denmark.

Fra, E. A., R. Saúl Salinas, and M. Valle Perea (2007). Distribución del pino del cerro, Podocarpus parlatorei Pilger (Podocarpaceae), en la provincia de Catamarca, Argentina. Liloa 44:99105.

Herrera, M., and B. Hennessey (2007). Quantifying the illegal parrot trade in Santa Cruz de la Sierra, Bolivia, with emphasis on threatened species. Bird Conservation International 17: 295-300.

Hijmans, R. J., S. E. Cameron, J. L. Parra, P. G. Jones, and A. Jarvis (2005). Very high resolution interpolated climate surfaces for global land areas. International Journal of Climatology 25: 1965-1978.

Hostetler, J. A., T. S. Sillett, and P. P. Marra (2015). Full-annualcycle population models for migratory birds. The Auk: Ornithological Advances 132:433-449.

Hueck, K. (1978). Los Bosques de Sudamérica. Ecología, composición e importancia económica. Agencia Alemana de Cooperación Técnica (GIZ), Berlin, Germany.

Ibisch, P. L., and G. Mérida (2008). Biodiversidad: La riqueza de Bolivia. Editoral Fundacion, Amigos de la Naturaleza, Santa Cruz de la Sierra, Bolivia.

IUCN (2014). The IUCN Red List of Threatened Species, version 2014.3. http://www.iucnredlist.org

Jennings, M. D. (2000). Gap analysis: Concepts, methods, and recent results. Landscape Ecology 15:5-20.

Joppa, L. N., S. R. Loarie, and S. L. Pimm (2008). On the protection of "protected areas." Proceedings of the National Academy of Sciences USA 105:6673-6678.

Kukkala, A. S., and A. Moilanen (2012). Core concepts of spatial prioritisation in systematic conservation planning. Biological Reviews 88:443-464.

Leopold, C. R., and S. C. Hess (2013). Multi-scale habitat selection of the endangered Hawaiian Goose. The Condor 15:17-27.

Liu, C., P. M. Berry, T. P. Dawson, and R. G. Pearson (2005). Selecting thresholds of occurrence in the prediction of species distributions. Ecography 28:385-393.

Lizárraga, L. (2012). Sistema de Informacion de Biodiversidad. Administración de Parques Nacionales, Ciudad Autónoma de Buenos Aires, Argentina. www.sib.gov.ar
Long, A. J., M. J. Crosby, A. J. Stattersfield, and D. C. Wege (1996). Towards a global map of biodiversity: Patterns in the distribution of restricted-range birds. Global Ecology and Biogeography Letters 5:281-304.

Lunney, D., R. L. Pressey, M. Archer, S. Hand, H. Godthelp, and A. Curtin (1997). Integrating ecology and economics: Illustrating the need to resolve the conflicts of space and time. Ecological Economics 23:135-143.

Malizia, L., S. Pacheco, C. Blundo, and A. D. Brown (2012). Caracterización altitudinal, uso y conservación de las Yungas Subtropicales de Argentina. Ecosistemas 21:53-73.

Margules, C. R., and R. L. Pressey (2000). Systematic conservation planning. Nature 405:243-253.

Margules, C. R., R. L. Pressey, and P. H. Williams (2002). Representing biodiversity: Data and procedures for identifying priority areas for conservation. Journal of Biosciences 27: 309-326.

Maria Mendoza, A., and A. Arita (2014). Priority setting by sites and by species using rarity, richness, and phylogenetic diversity: The case of Neotropical glassfrogs (Anura: Centrolenidae). Biodiversity and Conservation 23:909-926.

Marin-Togo, M. C., T. C. Monterrubio-Rico, K. Renton, Y. RubioRocha, C. Macias-Caballero, J. M. Ortega-Rodriguez, and R. Cancino-Murillo (2012). Reduced current distribution of Psittacidae on the Mexican Pacific Coast: Potential impacts of habitat loss and capture for trade. Biodiversity and Conservation 21:451-473.

Martínez-Freiría, F., H. Argaz, S. Fahd, and J. Brito (2013). Climate change is predicted to negatively influence Moroccan endemic reptile richness: Implications for conservation in protected areas. Naturwissenschaften 100:877-889.

McCarthy, D. P., P. F. Donald, J. P. W. Scharlemann, G. M. Buchanan, A. Balmford, J. M. H. Green, L. A. Bennun, N. D. Burgess, L. D. C. Fishpool, S. T. Garnett, D. L. Leonard, et al. (2012). Financial costs of meeting global biodiversity conservation targets: Current spending and unmet needs. Science 338:946-949.

Mendoza, E. A. (2005). El clima y la vegetación natural. In El clima del Noroeste Argentino (J. L. Minetti, Editor). Magna Press, Tucumán, Argentina. pp. 233-279.

Montenegro, C., M. Strada, M. Gasparri, M. G. Parmuchi, M. Mino, and F. Chomnalez (2012). Unidad de Manejo del Sistema de Evaluación Forestal, Monitoreo de los Bosques Nativos de Argentina. Direccion de Bosques, Secretaría de Ambiente y Desarrollo Sustentable, Buenos Aires, Argentina.

Navarro, G., and M. Maldonado (2002). Geografía ecológica de Bolivia: Vegetación y ambientes acuáticos. Editorial: Centro de Ecología y difusión Simón I. Patiño, Santa Cruz, Bolivia.

Pearce, J., and S. Ferrier (2000). Evaluating the predictive performance of habitat models developed using logistic regression. Ecological Modelling 133:225-245.

Phillips, S. J., R. P. Anderson, and R. E. Schapire (2006). Maximum entropy modelling of species geographic distributions. Ecological Modelling 190:231-259.

Politi, N., M. Hunter, and L. Rivera (2009). Nest selection by cavity-nesting birds in subtropical montane forests of the Andes: Implications for sustainable forest management. Biotropica 41:354-360.

Politi, N., M. Hunter, and L. Rivera (2010). Availability of cavities for avian cavity nesters in selectively logged subtropical 
montane forests of the Andes. Forest Ecology and Management 260:893-906.

Quiroga, P., and M. Gardner (2013). Podocarpus parlatorei. In The IUCN Red List of Threatened Species, version 2013.1. www. iucnredlist.org

Quiroga, P. G., S. Pacheco, L. R. Malizia, and A. C. Premoli (2012). Shrinking forests under warming: Evidence of Podocarpus parlatorei (pino del cerro) from the subtropical Andes. Journal of Heredity 103:682-691.

R Development Core Team (2014). R: A Language and Environment for Statistical Computing. R Foundation for Statistical Computing, Vienna, Austria. http://www.R-project. org

Renton, K. (2006). Diet of adult and nestling Scarlet Macaws in southwest Belize, Central America. Biotropica 38:280-283.

Renton, K., and A. Salinas-Melgoza (1999). Nesting behavior of the Lilac-crowned Parrot. Wilson Bulletin 111:488-493.

Rivera, L. (2011). Ecología, biología reproductiva y conservación del Loro alisero (Amazona tucumana) en Argentina. Ph.D. dissertation, Universidad Nacional de Córdoba; Córdoba, Argentina.

Rivera, L., N. Politi, and E. J. Bucher (2007). Decline of the Tucumán Parrot Amazona tucumana in Argentina: Present status and conservation needs. Oryx 41:101-105.

Rivera, L., N. Politi, and E. H. Bucher (2012). Nesting habitat of the Tucumán Parrot Amazona tucumana in an old-growth cloud forest of Argentina. Bird Conservation International 22:398410.

Rivera, L., N. Politi, E. H. Bucher, and A. M. Pidgeon (2013). Nesting success and productivity of Tucumán Parrots (Amazona tucumana) in high-altitude forests of Argentina: Do they differ from lowland Amazona parrots? Emu 114:4149.

Rivera, L., R. Rojas Llanos, N. Politi, B. Hennessey, and E. H. Bucher (2010). Status of Tucumán Parrot Amazona tucumana in Bolivia: Insights for a global assessment. Oryx 44:110-113.

Rodrigues, A. S. L., H. R. Akçakaya, S. J. Andelman, M. I. Bakarr, L. Boitani, T. M. Brooks, J. S. Chanson, L. D. C. Fishpool, G. A. B. Da Fonseca, K. J. Gaston, M. Hoffmann, et al. (2004). Global gap analysis: Priority regions for expanding the global protected-area network. BioScience 54:1092-1100.

Rojas Llanos, R. (2012). Análisis de las características y los cambios en el comercio de Psittácidos de Bolivia en los últimos treinta años. M.S. thesis, Universidad Nacional de Córdoba, Córdoba, Argentina.

Rosenfield, J. A. (2002). Pattern and process in the geographical ranges of freshwater fishes. Global Ecology and Biogeography 11:323-332.

Secretaría de Ambiente y Desarrollo Sustentable de la Nación (2012). Monitoreo de la Superficie de Bosque Nativo de la República Argentina: Periodo 2006-2011. Regiones Forestales Parque Chaqueño, Selva Misionera y Selva Tucumano
Boliviana. Direccion de Bosques, Secretaría de Ambiente y Desarrollo Sustentable, Buenos Aires, Argentina. http://obio. ambiente.gob.ar/multimedia/files/Monitoreo\%20de\%20 la $\% 20$ superficie\%20de\%20bosque\%20nativo\%20de\%20 la\%20Republica\%20Argentina.pdf

Slaght, J. C., S. G. Surmach, and R. J. Gutiérrez (2013). Riparian old-growth forests provide critical nesting and foraging habitat for Blakiston's Fish Owl Bubo blakistoni in Russia. Oryx 47:553-560.

Svancara, L. K., R. Brannon, J. M. Scott, C. R. Groves, R. F. Noss, and R. L. Pressey (2005). Policy-driven versus evidence-based conservation: A review of political targets and biological needs. BioScience 55:989-995.

Tear, T. H., P. Kareiva, P. L. Angermeier, P. Corner, B. Czech, R. Kautz, L. Landon, D. Mehiman, K. Murphy, M. Ruckelshaus, J. M. Scott, and G. Wilhere (2005). How much is enough? The recurrent problem of setting measurable objectives in conservation. BioScience 55:835-849.

Tella, J. L., and F. Hiraldo (2014). Illegal and legal parrot trade shows a long-term, cross-cultural preference for the most attractive species increasing their risk of extinction. PLOS One 9:e107546. doi:10.1371/journal.pone.0107546

Tella, J. L., A. Rojas, M. Carrete, and F. Hiraldo (2013). Simple assessments of age and spatial population structure can aid conservation of poorly known species. Biological Conservation 167:425-434.

Thuiller, W. (2004). Patterns and uncertainties of species' range shifts under climate change. Global Change Biology 10:20202027.

Thuiller, W., B. Lafourcade, R. Engler, and M. B. Araújo (2009). BIOMOD-A platform for ensemble forecasting of species distributions. Ecography 32:369-373.

U.S. Fish and Wildlife Service (1992). 50 CFR Part 15 RIN 1018AC15: Importation of Exotic Wild Birds to the United States; Final Rule Implementing the Wild Bird Conservation Act of 1992. Department of the Interior, Washington, DC, USA.

VanDerWal, J., L. P. Shoo, C. Graham, and S. E. William (2009). Selecting pseudo-absence data for presence-only distribution modeling: How far should you stray from what you know? Ecological Modelling 220:589-594.

Wetmore, A. (1926). Observations on the birds of Argentina, Paraguay, Uruguay, and Chile. Bulletin of the United States National Museum 133.

Woolaver, L. G., R. K. Nichols, E. S. Morton, and B. J. M. Stutchbury (2013). Feeding ecology and specialist diet of critically endangered Ridgway's Hawks. Journal of Field Ornithology 84:138-146.

Wright, T. F., C. A. Toft, E. Enkerlin-Hoeflich, J. Gonzalez-Elizondo, A. Albornoz, M. A. Rodriguez-Ferraro, F. Rojas-Suarez, V. Sanz, A. Trujillo, S. R. Beissinger, V. Berovides, et al. (2001). Nest poaching in Neotropical parrots. Conservation Biology 15: 710-720. 
APPENDIX TABLE 4. The set of 8 bioclimatic variables used in models of potential suitable Tucuman Parrot habitat, and their Pearson's correlation coefficients. The bioclimatic variables represent annual trends (e.g., annual mean temperature, annual precipitation), seasonality (e.g., variation in temperature and precipitation), and extreme or potentially limiting environmental factors (e.g., temperature of the coldest and warmest month, and precipitation of the wet and dry quarters). A quarter is a period of 3 mo. Data were obtained from the WorldClim database (http://www.worldclim.org/bioclim). $\mathrm{BIO}_{1}=$ annual mean temperature; $\mathrm{BIO}_{4}=$ temperature seasonality (standard deviation * 100); $\mathrm{BIO}_{5}=$ maximum temperature of warmest month; $\mathrm{BIO}_{6}=$ minimum temperature of coldest month; $\mathrm{BIO}_{12}=$ annual precipitation; $\mathrm{BIO}_{15}=$ precipitation seasonality (coefficient of variation); $\mathrm{BIO}_{16}=$ precipitation of wettest quarter; and $\mathrm{BIO}_{17}=$ precipitation of driest quarter.

\begin{tabular}{|c|c|c|c|c|c|c|c|c|}
\hline & $\mathrm{BlO}_{1}$ & $\mathrm{BIO}_{12}$ & $\mathrm{BIO}_{15}$ & $\mathrm{BIO}_{16}$ & $\mathrm{BIO}_{17}$ & $\mathrm{BIO}_{4}$ & $\mathrm{BIO}_{5}$ & $\mathrm{BlO}_{6}$ \\
\hline $\mathrm{BIO}_{1}$ & 1.0000 & -0.3641 & 0.4574 & 0.0469 & -0.5657 & 0.4502 & 0.8110 & -0.0844 \\
\hline $\mathrm{BIO}_{12}$ & -0.3641 & 1.0000 & -0.7864 & 0.5753 & 0.8514 & -0.7613 & -0.7190 & 0.7880 \\
\hline $\mathrm{BIO}_{15}$ & 0.4574 & -0.7864 & 1.0000 & 0.0469 & -0.9693 & 0.9902 & 0.8842 & -0.8834 \\
\hline $\mathrm{BlO}_{16}$ & 0.0469 & 0.5753 & 0.0469 & 1.0000 & 0.1005 & 0.0816 & 0.0211 & 0.1363 \\
\hline $\mathrm{BIO}_{17}$ & -0.5657 & 0.8514 & -0.9693 & 0.1005 & 1.0000 & -0.9642 & -0.9350 & 0.8638 \\
\hline $\mathrm{BlO}_{4}$ & 0.4503 & -0.7613 & 0.9902 & 0.0816 & -0.9642 & 1.0000 & 0.8832 & -0.8840 \\
\hline $\mathrm{BIO}_{5}$ & 0.8110 & -0.7190 & 0.8842 & 0.0211 & -0.9350 & 0.8832 & 1.0000 & -0.6399 \\
\hline $\mathrm{BIO}_{6}$ & -0.0844 & 0.7880 & -0.8834 & 0.1363 & 0.8638 & -0.8840 & -0.6399 & 1.0000 \\
\hline
\end{tabular}

APPENDIX TABLE 5. Area under the ROC curve (AUC) scores for models of the distribution of Tucuman Parrot nonbreeding habitat and breeding habitat, as indicated by the predicted distribution of pino blanco (Podocarpus parlatorei). The top 4 models within each set are shown in bold font. Ensemble (unweighted average of the top 4 models) nonbreeding habitat AUC score $=0.953 \pm$ 0.040 SD. Ensemble breeding habitat AUC score $=0.964 \pm 0.030$. The training AUC is the average ( \pm SD) of the training-only model across the 2 pseudoabsence replicates. The testing AUC score is the average ( \pm SD) across the 20 replicates used in cross-validation testing models. ANN = Artificial Neural Networks, CTA = Classification and Regression Trees, FDA = Flexible Discrimination Analysis, $\mathrm{GAM}=$ Generalized Additive Models, GBM = Generalized Boosted Models, GLM = Generalized Linear Models, MARS = Multivariate Adaptive Regression Splines, MaxEnt = Maximum Entropy, RF = Random Forest, and SRE = Surface Range Envelope.

\begin{tabular}{|c|c|c|c|c|}
\hline Model & Training model AUC score & SD & Testing model AUC score & SD \\
\hline \multicolumn{5}{|c|}{ Nonbreeding habitat } \\
\hline MaxEnt & 0.894 & 0.059 & 0.932 & 0.001 \\
\hline GBM & 0.875 & 0.058 & 0.963 & 0.000 \\
\hline RF & 0.870 & 0.093 & 1.000 & 0.000 \\
\hline FDA & 0.869 & 0.080 & 0.917 & 0.011 \\
\hline GLM & 0.842 & 0.100 & 0.927 & 0.005 \\
\hline GAM & 0.778 & 0.182 & 0.932 & $N A^{a}$ \\
\hline MARS & 0.762 & 0.128 & 0.831 & 0.022 \\
\hline ANN & 0.735 & 0.135 & 0.714 & 0.227 \\
\hline CTA & 0.734 & 0.109 & 0.827 & $N A^{a}$ \\
\hline SRE & 0.702 & 0.111 & 0.758 & 0.008 \\
\hline \multicolumn{5}{|c|}{ Breeding habitat } \\
\hline GBM & 0.912 & 0.066 & 0.977 & 0.003 \\
\hline MaxEnt & 0.907 & 0.071 & 0.945 & 0.005 \\
\hline RF & 0.901 & 0.082 & 1.000 & 0.000 \\
\hline FDA & 0.898 & 0.080 & 0.932 & 0.010 \\
\hline GLM & 0.882 & 0.070 & 0.933 & 0.005 \\
\hline CTA & 0.874 & 0.045 & 0.888 & 0.007 \\
\hline MARS & 0.842 & 0.079 & 0.888 & 0.021 \\
\hline SRE & 0.788 & 0.110 & 0.820 & 0.008 \\
\hline ANN & 0.774 & 0.123 & 0.934 & 0.016 \\
\hline GAM & 0.688 & 0.150 & 0.941 & NA \\
\hline
\end{tabular}

${ }^{a} \mathrm{NA}$ values indicate that 1 of the training model replicates failed to complete, and only 1 AUC score is available. 